\title{
Realising the Right of the Child to Participate in the Criminal Process
}

\section{Introduction}

Ensuring that children in conflict with the law can participate meaningfully in criminal proceedings is an integral part of ensuring that a State's youth justice system is child-friendly and rights-compliant. Children in conflict with the law, like adults, enjoy the protection of the right to a fair trial as a fundamental right. This guarantee is codified in a number of international instruments, and ensuring that children are able to participate effectively is a key aspect of this (Arthur, 2016: 223). Children in conflict with the law require additional supports in order to ensure that their right to participate is meaningful in practice (Rap, 2016: 99), and therefore vindicating this right poses real challenges at the national level for States.

There is a need for States to take positive steps in order to support young people's participation. This can be achieved by legislation that provides strong entitlements to information and other support mechanisms, as well as through the modification of procedures by courts and professionals involved in the criminal justice system. The aim of this article is to examine the efforts that have been made to facilitate the participation of children in conflict with the law in criminal processes in the Republic of Ireland, and to compare this with the steps taken in New Zealand.

A comparison of practice in Ireland and New Zealand provides a useful insight into the challenges that emerge in practice in the implementation of law and policy that aims to uphold children's rights in the trial process. While there are similarities in specific legislative provisions in the New Zealand and Irish youth justice legislation indeed, the New Zealand system of youth justice provided significant inspiration for the Irish legislature at the introduction of the Children Act 2001 (Dáil Debates, 2000) - the differences in the legal frameworks, in the role of the courts, and in the procedures followed, impact the rights of children in conflict with the law in different ways. It is worth noting that youth justice law in both countries is also in a period of transition. Significant changes have recently been introduced to the Oranga Tamariki Act 1989 (formerly known as the Children, Young Persons and their Families Act 1989) and are in the process of being rolled out, though many of the legislative changes remain uncommenced at the time of writing. Similarly, in Ireland, the Children Act 2001 is entering a period of review and reconsideration. Through an examination of the relevant legislative frameworks, guidelines, and practice in each of these countries, the discussion aims to highlight some of the challenges that arise for countries seeking to realise the child's right to effective participation, as well as the features of the systems that can help to support children in this context. These are relevant not only to the two countries discussed, but to all States seeking to adapt their legislation and legal systems in order to meet their obligations under the UNCRC and other international standards.

The article will first discuss the relevant international standards and guidelines that set out the rights children are entitled to in criminal processes. It then moves on to consider how these standards are realised at the domestic level. In particular, it focuses on how the legislative framework and the way in which provisions are implemented impact the child's right to participate at two key stages: 1) at the pretrial and investigation stage, and; 2) during the trial process.

\section{International standards and guidelines}

International standards at both the UN and European level guarantee the child's right to participate in criminal proceedings. The rights of children in conflict with the law 
are set out in Articles 37 and 40 of the United Nations Convention on the Rights of the Child (UNCRC). Further, Article 12 of the UNCRC recognises that all children capable of forming his or her own views should have the opportunity to express them freely in any proceedings affecting him or her, and that due regard should be given to these views, in line with their age and maturity. It has been noted that the obligation for States to implement this right fully is a strict one (Parkes et. al., 2015: 442). Article 40 details the due process rights which children are entitled to. These guarantees are applicable to children "alleged as, accused of, or recognised as having infringing the penal law", and therefore apply from the earliest stages of children's contact with criminal justice authorities. Article 40.2 provides a number of specific protections to the child in conflict with the law, which include a right to be informed promptly, to access legal or other appropriate assistance in the preparation of the defence and through the adjudication process, to have his or her parents or guardians informed, to an interpreter if necessary, and to full respect for his or her right to privacy throughout the proceedings. These individual guarantees are highly relevant to the ability of the child to participate meaningfully.

The scope and meaning of these guarantees are described further in supporting guidelines. In particular, there is a strong emphasis on the need for the child's participation to be "effective". The UN Standard Minimum Rules for the Administration of Juvenile Justice ("the Beijing Rules") emphasise the need for proceedings to be "conducted in an atmosphere of understanding, which shall allow the juvenile to participate therein and to express herself or himself freely" (Rule 14.2). Further, the Committee on the Rights of the Child, commenting on the scope and application of Article 12, have made it clear that the child's right to express his or her views must be "fully respected and implemented throughout every stage of the process of juvenile justice" (Committee on the Rights of the Child, 2009: para 57). The child's right to be directly heard by authorities including the police, the prosecutor and the investigating judge is noted, and it is stressed that the right to effective participation includes both the right to prompt and direct information and the need for proceedings to be held in an atmosphere which supports this participation (Committee on the Rights of the Child, 2009: paras 58, 60).

General Comment No. 10 on children's rights in juvenile justice also affirms the right to effective participation as a fundamental aspect of the child's right to a fair trial. This includes a need to ensure that the child understands the proceedings and any decisions taken, and notes "modified courtroom procedures and practices" may be required (Committee on the Rights of the Child, 2007: para 46). It has been commented that the true exercise of autonomy in this context goes beyond mere understanding of the proceedings, and encompasses the ability to make evaluative judgments (Arthur, 2016: 224). Modifications may include "translation" of legal jargon, ensuring that cases be dealt with in non-intimidating and child-sensitive settings, that language appropriate to the child's age and level of understanding should be used, and that court sessions should be adapted to the child's needs through the incorporation of short breaks and the minimization of distractions. Both Ireland and New Zealand are party to the UNCRC, and so have an obligation to take steps to realise the child's rights in this area.

Standards which re-iterate and re-emphasise the need to support the child's effective participation at the European level are also applicable in the Irish context. The Council of Europe Guidelines on child-friendly justice emphasise the practical steps which should be taken in order to make the right meaningful, including familiarising the child with the courtroom in advance where possible, minimising disruption and 
distractions during court sessions, and ensuring that specially-trained legal professionals are availble. The commentary on these guidelines emphasise the need for measures to go beyond mere tokenistic gestures, and advise that procedures should be "transparent and informative, voluntary, respectful, relevant, child friendly, inclusive, carried out by trained staff, safe and sensitive to risk and, finally, accountable" (Council of Europe, 2010: 82).

A number of judgments of the European Court of Human Rights (ECtHR) have also highlighted that a failure on the part of the State to ensure that children can participate meaningfully in criminal proceedings may lead to a violation of their rights under Article 6 of the European Convention on Human Rights. In the cases of T. v. the United Kingdom and $V$. v. the United Kingdom (1999) 30 EHRR 121, the ECtHR found that the public trial of two 11-year-old boys in the UK Crown Court, which had attracted substantial media attention, had resulted in a breach of their Article 6 rights as they had been unable to participate effectively. The ECtHR highlighted the need to take the age, level of maturity and emotional capacities of young defendants into account, and the need for steps to be taken to support young people's ability to understand and participate in the proceedings (T. v. the United Kingdom, para. 84). The scope and meaning of "effective participation" was developed further by the ECtHR in the case of S.C. v. the United Kingdom (2005) 40 EHRR 10. Here, although a number of steps had been taken by the State authorities to modify the trial process - which also took place in the Crown Court - for an 11-year-old defendant with limited intellectual capacities, this was not considered sufficient to vindicate his rights under Article 6. It was held that while "effective participation" would not necessarily require a detailed understanding of every technical aspect of the trial, it did require that the child be able to have a "broad understanding of the nature of the trial process and of what is at stake for him or her, including the significance of any penalty which may be imposed" (S.C. v. the United Kingdom, para 29). Importantly, the need for the State to take positive steps to ensure that the child's Article 6 rights were vindicated was strongly emphasised.

Subsequent judgments have also confirmed that this entitlement extends beyond the trial process and, applies from the earliest stats of criminal proceedings, including police questioning (Martin v. Estonia (2003) EHCR App. No. 35985/09). This was affirmed in the case of Salduz v. Turkey (2000) 49 EHRR 19, where the ECtHR held that the vulnerability of young people, coupled with the often increasing complexity of criminal legislation, could only be properly compensated for by the assistance of a lawyer to ensure respect for the accused's right against self-incrimination. The ECtHR emphasised that any restriction of this right should only be justified in exceptional cases with reference to compelling reasons (Salduz, paras 54-55). The ECtHR jurisprudence in relation to effective participation makes it clear that a child defendant's rights under Article 6 of the ECHR may be breached if a State does not take sufficient positive steps in order to guarantee that the child understands the nature and significance of the proceedings, and to reduce the possibility of fear and intimidation accompanying the proceedings (Parkes, 2013: 171; Kilkelly and Forde, 2016: 462-463).

\section{Realising the child's right to effective participation in practice}

The international standards and guidelines make it clear that positive, meaningful steps are required to protect the child's right to participate. It is notable that the UNCRC standards are minimum requirements only, and additional measures may be adopted by States in order to support children's participation more fully. The 
international standards represent an important acknowledgement of the different capacities of children as compared to adults. Weijers, in a study of children's communication in the courtroom, highlighted that children do not have the capacity to communicate, or to apply reasoning, in the same way as adults (Weijers, 2004: p.25). Developmental psychological research has also highlighted the difference in children's cognitive capacities as compared with adults (Rap, 2016: 100; Grisso et al,, 2003). Modifications to support participation should take into account that children may be able to concentrate for shorter periods of time (Arthur, 2016: 227), to provide clear explanations of what is being said, and to encourage legal professionals to engage meaningfully with children (Weijers, 2004: 26-27). It has also been noted that the rehabilitative function of the court, and its ability to help the child appreciate the consequences of his or her offending, can be significantly undermined if the child cannot understand or participate effectively (Arthur, 2016: 227; Weijers, 2004).

Ensuring that the child's right to effective participation is meaningful in practice requires both strong legislative provisions and the effective implementation of these provisions in practice. The courts also have a pivotal role to play here. The role of the courts in interpreting relevant statutory guarantees, and of fair trial guarantees which may exist under Constitutional law, can be critical in determining the scope and level of protection given to the right. Hollingsworth has noted the importance of a rights-based framework in youth justice to allow the court to focus on the child's status as child, as well as merely of an offender (Hollingsworth, 2007: 47). Equally, practice directions setting out court procedures, particularly those ensuring that steps are put in place to create an atmosphere conducive to the child's participation, can provide insight into how space is made for the voice of the child in practice.

An examination of two jurisdictions, Ireland and New Zealand, illustrates how the law can operate to support children to participate effectively both during court hearings and during the investigation stage. While the youth justice systems in place in each country have developed differently in several significant respects, several provisions the Irish Children Act 2001 initially took their inspiration from the New Zealand youth justice system, which was developed primarily in the Oranga Tamariki Act 1989 (Kilkelly, 2006: 36, 78).

However, differences in the legislative provisions designed to support young people's participation, and in the implementation of these guarantees, have impacted differently on children's ability to participate effectively. Equally, the youth justice systems of each country are underpinned by different philosophies and organising principles (Forde, 2018). While, in simple terms, both Ireland and New Zealand are "justice"-based systems, with a focus on the use of criminal justice agencies such as the courts and police to respond to youthful offending, both systems have been significantly adapted to take account of the needs and welfare of children in conflict with the law.

In Ireland, substantial emphasis is placed on diverting children from formal justice procedures and the courts, and on reducing the negative impact of criminal justice system contact on young people through recognition of the particular vulnerabilities of children and marked reductions in the use of detention as a sanction (Walsh, 2008; Kilkelly, 2008; Kilkelly, 2014). New Zealand, also, has adapted its system to take account of the needs and welfare of children. The statutory guiding principles contained in s.208 of the Oranga Tamariki Act place a strong emphasis on diversion, legal protections for children, and the need to take into account the underlying needs and welfare of the children involved (Becroft, 2006; Maxwell \& Morris, 2006). Further, the strong focus on strengthening the family and whānau in the New Zealand 
context has led to substantially altered procedures; restorative justice processes play a particularly important role in New Zealand youth justice, and decision-making power shifts at some points in the system from the courts and legal authorities to the young person and their families (Becroft, 2006; Cleland \& Quince, 2014: 139).

Although both countries continue to face challenges in making the child's right to participation in this area effective, the discussion in the following sections aim to highlight important ways in which the law can function to strengthen the voice of the child in criminal proceedings.

\section{Effective participation at the pre-trial and investigation stage}

It is important that children are enabled to participate from the earliest stages of criminal proceedings, including at investigation. It has been noted that the police station can be an "essentially adversarial if not confrontational" environment, and in light of this, young people are inherently disadvantaged and require special protections. (Parry, 2006; 375). A number of provisions of Irish law aim to address this issue.

The primary legislation governing youth justice in Ireland is the Children Act 2001. Part VI of the Children Act outlines the treatment of child suspects in Garda (police) custody, and is particularly relevant when the child is being questioned. Section 55 requires Gardaí, in all investigations of offences committed by children, to carry out their duties "with due respect for the personal rights of the children and their dignity as human persons, for their vulnerability owing to their age and level of maturity and for the special needs of any of them who may be under a physical or mental disability". Aside from this general principle, specific provisions relating to the type of information to be given to the child and to the procedure to be followed when interviewing children have a direct bearing on children's ability to participate.

Section 57 of the Children Act requires that when the child is arrested, they should be given information detailing the alleged offence and their entitlement to consult a solicitor. They should also be given information about how to access this legal advice. This information should be given "in a manner and in language that is appropriate to the age and level of understanding of the child". The legislation also requires that parents or guardians be notified of the arrest "as soon as practicable". A child detained by the Gardaí should neither be questioned nor asked to make a written statement unless a parent or guardian is present, or, if a parent or guardian is not available, in the presence of "another adult" other than a member of the Gardaí. Section 61 further provides that if a child asks to consult with a solicitor, he or she should not be asked to make a statement until a reasonable time has been allowed to facilitate this.

While these statutory provisions represent important aspects of the child's right to participation, and go some way to ensuring that these requirements are met, they are nonetheless a little bare on the detail, in that the scope or meaning of the entitlements is not elaborated upon in any significant way. Section 58 outlines that the parents or guardian of the child must be informed of their arrest, while s.61 stipulates that if a parent or guardian is absent while the child is making a statement, "another adult" must be present. It does not stipulate that this adult must be appropriate, nor what the role of the adult might be beyond mere presence. This is a particular issue given the potential complexity of the role the appropriate adult may be required to play (Parry, 2006). It has been suggested, however, that relatives of the young person may not always be suitable to act as an appropriate adult, (Kemp et. al., 2011: 38), and therefore deeper consideration of what the role entails is needed. It has been noted in 
the UK that ensuring access to appropriate adults can have an impact on requests for legal representation (Kemp et. al., 2011: 37), and therefore may have a significant impact on the way in which children's rights are realised.

The issue was considered by the Irish courts in the case of D.P.P. v. Onumwere [2007] IECCA 48, involving a 17-year-old suspect. An adult, in the form of an interpreter, was present with him, and he also received visits from his girlfriend, who was an adult. In a challenge to the adequacy of these arrangements, the applicant contended that a social worker assigned to him in the context of the asylum process should have been contacted. However, the court ultimately held that it was "satisfied in the circumstances of this case including the applicant's age, his access to his adult girlfriend and the need for an adult who could communicate with the applicant in his own language that the involvement of... [the interpreter] for the purposes of the subsection complied with the requirements of section 58." The age of the applicant, and the fact that he had been living independently were significant factors influencing the court's decision. Parry has suggested that the role of an appropriate adult should go beyond a mere translator of the language, that suggests that they should facilitate dialogue and understanding, and should ideally be centred on "notions of confidence and trust" (Parry, 2006: 380). The Irish courts, in this case, however, did not consider the role of an appropriate adult in this light.

However, the opposite conclusion was reached by the Irish courts in the case of D.P.P. v. K.D. [2016] IECA 341. Here, the failure of a peace commissioner who was fulfilling the role of the "other adult" to suggest that the child may wish to consult a lawyer when he began to make admissions during the course of Garda interviews was enough for the court to find that he had been "incapable of fulfillign the role of responsible adult". While this conclusion indicates that an adult fulfilling this support role has some positive duties, the scope and nature of these duties is not clear, either in the statute itself, or in the guidance that has emerged thus far from the courts on this point. While the decision of the court in K.D. recognised that children need specific types of support when being questioned by the police, the lack of further elaboration of the requirements here remains problematic. The sparseness of the statutory provisions here, particularly with regard to the appropriateness of the adult, and the lack of detail around the adult's purpose, appears to act as a barrier to ensuring that meaningful support is given to the child in this context.

Similarly, the child's right of access to a solicitor is limited in important ways. The right of an accused person to access a solicitor has been recognised as a Constitutional right under Article 38.1, which guarantees the right to a trial in due course of law (D.P.P. v. Healy [1990] 2 I.R. 73). The ability to claim a breach of a defendant's Constitutional rights can provide a powerful legal remedy, and a denial of the right of reasonable access to legal advice can result in a defendant's detention being held to be unlawful (O'Malley, 2009: 228). In Irish criminal processes generally, the right to legal advice is confined to access to a solicitor prior to being interviewed, and does not extend to an entitlement to having a solicitor present during Garda interviews (Lavery v. Member in Charge, Carrickmacross Garda Station [1999] 2 I.R. 390; D.P.P. v. Doyle [2017] IESC 1). Due process rights under Article 38.1 of the Irish Constitution have, in the past, been interpreted somewhat differently in relation to child defendants as compared with adult defendants (B.F. v. D.P.P [2001] 1 IR 656; Donoghue v. D.P.P. [2014] IESC 56). This raises the question of whether the special vulnerability of young people in this situation could give rise to a recognition of the need for increased access to legal advice during the questioning process under the 
Constitution, in order to fully vindicate the young person's right to participate effectively in all stages of the proceedings.

The Irish courts had the opportunity to consider whether a young person with severe learning and intellectual disabilities and mental health difficulties should have the right to have a solicitor present during Garda questioning in J.M. (a minor) v. Member in charge in Coolock Garda Station [2013] 2 IR 175. It was argued on behalf of the applicant that, in light of his particular vulnerabilities and the complex and technical nature of the legal issues involved, the refusal of the Gardai to allow him to have his solicitor present with him during his questioning amounted to a breach of his right to access to legal advice sufficient to render his detention in Garda custody unlawful. However, the High Court declined to recognise that the applicant had any entitlement to have his solicitor present with him during questioning, emphasising that he had had an opportunity to consult with his solicitor prior to the interview. The refusal to extend the understanding of the scope of the right to access legal advice during the course of police questioning either in light of the applicant's age or in light of his particular intellectual disabilities and other vulnerabilities may seriously hamper the ability of the child to participate in an active and meaningful way, as required by the international standards. The impact of this refusal on J.M.'s ability to participate effectively in the proceedings, or other potential consequences for his right to a fair trial, were not, however, considered in detail by the court. It is worth highlighting that the right of access to a solicitor should be seen as additional to, and not a substitute for, the assistance of a parent or other appropriate adult. While Garda policy has now changed to allow the presence of a solicitor if an accused requests it (An Garda Siochána, 2015), this is a matter of policy and not, at present, a legal right.

The Irish courts have not had the opportunity to consider the meaning or scope of the right to "effective participation" of young people in conflict with the law, either in the context of Article 38.1 of the Constitution, or in light of the ECtHR jurisprudence. While Part VI of the Children Act 2001 sets out a number of statutory requirements around the investigation of children for criminal offences, the remedies for breach are few. Section 66 provides that a failure by Gardaí to observe the procedural requirements set out in ss.56-63 will not affect the lawfulness of the detention of the child nor will it affect the admissibility of evidence obtained in breach of these rules, although individual Gardaí may be liable to disciplinary proceedings. This lack of significant statutory remedies for the child for breach of the procedural safeguards fundamental to the effective realisation of the right to participation seriously lessens the potency of these provisions.

In comparison, the procedural safeguards set out in the New Zealand Oranga Tamariki Act 1989 are substantially more robust. It is worth noting that s.208 of the Act sets out a number of central principles that must underpin the implementation of the youth justice provisions. This makes s.208 highly significant, as the specific provisions contained in the Oranga Tamariki Act should be interpreted in light of these principles. In addition, the new s.5 of the Oranga Tamariki Act stipulates that "a child or young person must be encouraged and assisted, wherever practicable, to participate in and express their views about any proceedings, process, or decision affecting them, and their views should be taken into account." While this section has not yet been commenced, this represents a strong principle that children should not only be allowed, but should be assisted to participate in all matters affecting them. A key provision of s.208 relevant to the realisation of the child's right to participate is s.208(h), which provides that children and young people are entitled to special protections during the course of investigations of criminal offences. 
The legislation goes on to enumerate a number of protections applicable to police investigations of criminal offences allegedly committed by young people in ss.214232 of the Oranga Tamariki Act. The provisions deal with issues around arrest, the right to legal representation, and the explanations of rights that must be given to children and young people prior to questioning by the police. These protections are critical aspects of ensuring that the right of the child to participate effectively in criminal proceedings are upheld. The importance of these provisions, and the seriousness with which the New Zealand courts have regarded breaches of these statutory protections, has been the subject of comment by Lynch:

"A ground breaking aspect of the...Act was the constraints the legislation placed on police power over young people. The legislation provides robust protections for young suspects when being questioned and investigated by the police. Inadmissibility of the evidence is the sanction for police non-compliance. The judiciary continue to strongly uphold these provisions, placing particular emphasis on the vulnerability of young people." (Lynch, 2016: 139)

One of the interesting aspects of these provisions is the detailed nature of the explanations to be given to young people by police before questioning can commence, under s.215. The case of $R$. v. Z. [2008] 3 NZLR 342 sets out clearly what is required. Explanations are not merely to be a bare statement of rights, but rather they require police to ensure that young people understand the meaning and significance of these rights. The Court emphasised the principle under s.208(h) of the Oranga Tamariki Act that children are entitled to special protections during investigation. Glazebrook $\mathrm{J}$ elaborated on how police should give these explanations to children. They should use language appropriate to the age and understanding of the child, ensure questioning takes place at age-appropriate times and under age-appropriate conditions, and should take into account any special characteristics such as medical condition or disability. These requirements mirror many of the guidelines of the international standards in this area. It is significant, too, that the court emphasised that the explanations had to be tailored to the understanding of the individual child. In emphasising understanding, the court appeared to take a particularly child-centred approach to the interpretation of the meaning and scope of this entitlement (see further Lynch, 2008b: 358).

The Oranga Tamariki Act also stipulates that children and young people are entitled to have a lawyer or another nominated person present when they are making a statement. The New Zealand courts have also considered the practical meaning of this protection. In the case of S. v. Police (14 March 2006), HC, Auckland, CRI 2004-404515 , the role of the nominated person was described as being a safeguard to ensure that the police carried out their duty to explain under s.215, and to provide the young person with having a sense of security in deciding to answer questions and during the interview itself. The role of the nominated person did not extend so far, however, as to include a requirement to intervene during the interview as a lawyer may have done.

The consequences of non-compliance with these procedures can be significant. Section 221(2) of the Act provides that a failure to comply with the procedural protections will render the evidence obtained inadmissible, although this is subject to an assessment of "reasonable compliance" with the requirements under s.224. The question of what might constitute "reasonable compliance" has also been considered in the case of $R$. v. Irwin [1992] 3 NZLR 119. Here, a 15-year-old defendant was given the adult caution on arrest, and the police did not make any reference to his entitlement to consult with a lawyer or other adult, and to have them present during the interview. The explanation given by the police of his rights were only provided after a 
period of questioning in which the defendant had already made significant admissions. The court, in finding that there had been a breach of his rights, held that there must be reasonable compliance with all three elements - the requirement to provide explanations about the young person's rights, to consultation with a lawyer or another adult, and to have a nominated person present during the interview. In this case, the Court held that the breaches were significant on an individual basis, and when looked at cumulatively, were overwhelming, and therefore could not amount to reasonable compliance.

The protections contained in the Oranga Tamariki Act are significantly more detailed than those contained in Part VI of the Irish Children Act 2001. While a significant gap in this area is the lack of research in either country that documents children's experiences, perspectives, and levels of understanding when being questioned by police, in New Zealand the more robust and detailed statutory protections appear to have translated into more significant judicial statements about the importance and scope of these protections. In contrast, the Irish case law has generally dealt with more vague provisions, and without similar guiding principles comparable to those contained in s.208 of the Oranga Tamariki Act. It seems clear that the guiding principle contained in s.208(h) that children are entitled to special protections during criminal investigations has provided a protective lens through which these provisions have been viewed and interpreted by the courts (Lynch, 2016, 31-32). While empirical research is needed to document and examine the lived experiences of children being questioned by police, the strong protection of children's rights both in legislation and by the judiciary is important to uphold the right of the child defendant to participate meaningfully, and with sufficient understanding of his or her rights and of the supports which he or she is entitled to in the questioning stage.

\section{Effective participation at trial}

Returning to Ireland, the Children Act 2001 acknowledges the importance of the child's participation in court processes. Part VII of the Children Act establishes the Children Court as the venue for the trial of the majority of offences committed by children. A number of provisions are relevant to supporting the participation of the child in the Children Court. Section 91 of the Children Act mandates that the parents or guardian of children being tried for criminal offences must attend all stages of the proceedings, unless they are excused by the judge if he or she is of the view that it would not serve the interests of justice. Section 94 also limits those allowed to attend Children Court; this limitation is an important aspect of ensuring that an environment that lessens any feelings of intimidation is provided to support children's participation.

Section 96 of the Children Act is particularly important, as it sets out a number of key principles relating to the exercise of criminal jurisdiction over children. These principles apply both to the Children Court and to the trial of children in any other court. It is significant that the scope of this protection is extended to children tried in adult courts. In particular, s.96(1)(a) provides that courts must have regard to the principle "that children have rights and freedom before the law equal to those enjoyed by adults and, in particular, a right to be heard and to participate in any proceedings of the court that can affect them". This is an important acknowledgement of the need to ensure that children are able to participate. The words "in particular" emphasise the importance accorded to the right of the child to be heard and to participate. While this section has not been subject to significant judicial comment or interpretation, it provides an important acknowledgement of this right. 
Translating this statutory principle into practice, however, appears to have posed challenges. Studies undertaken of practice in the Children Court have highlighted that real barriers exist to children's effective participation in courtroom procedures. A National Study carried out on the Children Court in 2007 (Carroll et. al., 2007) provided insights into the backgrounds and offending behaviour of children appearing before the Children Court. The report noted that where significant delays had taken place between the commission of the offence and the child's appearance in court, it could have a negative impact on the ability of the child to understand the proceedings (Carroll et. al., 2007: 41). In a follow-up to this study, Kilkelly noted several concerning trends which emerged during the observations. These indicated that children's level of participation overall in the proceedings was low, and moreover, suggested that children did not understand what was happening during the proceedings. In particular, it was commented that engagement with young people in the Children Court was extremely low, and in 55\% of cases no communication whatsoever took place between the judge and the young person. Further, observations were made which indicated that the young person was not following, was not engaged in, or did not understand the procedure (Kilkelly, 2008: 51). Seymour and Butler subsequently commented that a lack of understanding amongst young people where they had been remanded on bail by the court impacted negatively on young people's ability to comply with the terms of their bail, and thus to avoid being detained (Seymour and Butler, 2008: 44-46). These findings are highly concerning. Not only are such practices manifestly out of line with the requirements of the international standards relating to effective participation, a lack of engagement or understanding by young people is likely to have a knock-on effect on the level of compliance with measures or sanctions imposed by the court.

However, a number of positive steps to address low levels of participation have been undertaken since then. While we do not have a more recent evaluation of the Children Court to measure the impact of these initiatives, the push by the Courts Service and the judiciary to address these deficits is very welcome. A Practice Direction for the Children Court issued by the President of the Circuit Court in January 2014 seeks to ensure compliance with young people's rights under the Constitution and under the international standards, including the UNCRC, the Beijing Rules, and the European Convention on Human Rights. The Direction sets out a number of important rules impacting on the child's ability to participate. It contains rules on who may attend a Children Court hearing, the adaptation of the Children Court environment, and the expectations of legal practitioners and professionals involved in such cases. These provisions are important, particularly given observations made in the context of child care proceedings in the District Court in Ireland about the physical environment; these same facilities are often also used by the Children Court. A recent study commented that the environment did not afford sufficient protection to children's privacy, could contribute to feelings of intimidation experienced by children, and was generally deemed "unsuitable" for children, and to "fall far short of...the essential pre-requisites to child participation" (Parkes et. al., 2015: 429-430). The Practice Direction takes some steps towards addressing this, and is aimed at reducing the formality of the courtroom proceedings overall; restricting media presence in the Children Court, allowing the child to sit close to members of his family during proceedings, and facilitating requests by the young person to visit the courtroom out of business hours before the hearing are important measures to support the child's meaningful participation. These steps are in line with the international standards, and represent important procedural modifications aimed at supporting children's participation. 
The Practice Direction also has its limitations, however. An important limitation is that the Direction is applicable only to the Children Courts in operation in the Dublin Metropolitan region, and does not extend to Children Courts in other locations, nor to cases where children are tried in the higher courts. It is also notable that the Direction does not set out any requirements in relation to engagement with young people by judges. Instead, it focuses on the duties of legal representatives, highlighting the need for legal representatives to draw the court's attention to any special issues that the young person may have. While Irish data on the level of communication difficulties amongst young people in conflict with the law does not exist, international research has suggested that a significant percentage of young people in conflict with the law have either communication difficulties or learning disabilities (Arthur, 2016: 233), both of which can seriously impact the ability to participate meaningfully in criminal processes. Setting out a procedure wherein any communication difficulties, intellectual or learning difficulties, or mental health difficulties which may impact on a child's ability to participate is very important so that appropriate arrangements can be made.

The issue of training is also significant here. While s.72 of the Children Act 2001 requires that a District Court judge shall participate in relevant training or education courses required by the President of the District Court before transacting Children Court business, this is the only statutory requirement in relation to training for professionals involved in the Irish youth justice system. The low levels of formal training amongst legal professionals on children's rights and youth justice, and the lack of widespread and systematic education for youth justice has been the subject of criticism, and has been highlighted as a significant area where improvements need to be made (Kilkelly, 2014: 223). The lack of training for lawyers representing young people, in particular, is particularly concerning if they are to have the responsibility of raising any particular vulnerabilities or issues the child may have which may hinder their participation. The lack of training for judges is also a matter of concern; the communication styles and skills of judges in the District Court in child care proceedings were noted to vary greatly in Parkes' study (Parkes et. al., 2015: 432). Further, it has been noted in the UK that the introduction of other special measures designed to facilitate participation for child witnesses would have little value "if the prevailing practices and underlying cultures of practitioners are not adapted to better suit their needs" (Hall, 2009: 85). In light of such concerns, it seems clear that increased investment in training is needed so that legal professionals are equipped to engage with young people and to support their participation in a child-centred youth justice process.

A further positive development made recently in Ireland is the introduction of a Bench Book for the Children Court judiciary in 2015. The Bench Book provides guidance to judges on how the court should operate. Important issues such as the demeanour of the District Court judge, the support provided to the child by a family member or other suitable person, and the time and length of the court session are highlighted as potentially impacting on the child's capacity to give evidence. Issues such as using child-appropriate language, and of allowing breaks in giving evidence where necessary are all important steps to ensure that there is space for a child's voice in the criminal process. Importantly, the possibility appointing an intermediary, under s. 6 of the Criminal Procedure Act 2010 where the interests of justice require it may function as a particularly important mechanism for ensuring that the voice of the child is heard. In the UK, it has been noted that intermediaries' contributions were generally found to be positive, and helped to facilitate communication and reduce the 
stress of young people (Stone, 2010:182). Similarly, court support workers provided to young people in adult courts in Scotland were found to help demystify the process, to help young people understand their rights and the court process; this was found to have a knock-on effect on outcomes for young people (Deuchar \& Sapouna, 2016).

Finally, it is worth commenting that Part VIII of the Children Act 2001 also makes provision for the Children Court to refer a young person to a family conference, where an action plan will be drawn up for the child, and submitted to the court for approval. This echoes the procedure followed in the New Zealand Youth Courts, and may provide the potential for more child-friendly procedures that help facilitate more effective participation by the young person. However, the most recent statistics by the Probation Service, the organisation with responsibility for organising such conferences, extremely low numbers of young people were referred by the courts for a conference. Only 37 young people were referred in 2015, 36 in 2014 and 50 young people in 2013 (Probation Service, 2015: 49). Therefore, it appears that a key aspect of the legislation is not being fully implemented.

While a number of very positive steps have been taken in recent years in order to support young people to participate more effectively in criminal proceedings, challenges clearly remain for the realisation of the right of the child to participate in Ireland. In the absence of more up-to-date evaluations showing more positive outcomes for young people in this area, the observations of the Children Court practice in 2007 continue to give cause for concern. The lack of systematic and robust training for youth justice professionals, particularly judges and lawyers, is especially problematic.

In New Zealand, statutory provisions designed to ensure children can participate in proceedings have recently been strengthened. A new s.11 was inserted into the Oranga Tamariki Act by the Children, Young Persons and their Families (Workforce, Advocacy and Age Settings) Amendment Act 2016 and sets out the positive duties of courts, of FGCs, and other bodies taking decisions about children under the legislation to encourage and assist children to participate in the proceedings, to facilitate the direct hearing of the child, and to provide assistance to any child who has difficulties expressing his or her views. These measures came into force on $1^{\text {st }}$ April 2017.

In comparing issues around the participation of young people in court in New Zealand, it must be recognised that the New Zealand Youth Court processes have a number of distinguishing features that have a bearing on young people's participation. The place of the family group conference (FGC) is especially significant. Where a charge is put to a young person, and it is "not denied", an FGC must take place (see Lynch, 2016: 189-190). The primary decision-making function in relation to the measures to be taken is vested in the FGC, and the plan submitted to the Youth Court for approval. Evidence suggests that FGC plans are rarely altered by the Youth Court judge (Cleland \& Quince, 2014:140).

The use of the FGC as a central aspect of the Youth Court process raises a number of interesting procedural questions that impact on the right to effective participation. Far from the FGC, a restorative justice process, being a panacea, a number of concerns have been raised about its operation. While it is acknowledged that theoretically, at least, the FGC should facilitate more effective participation by young people, this has been found not to be the case in practice (Lynch, 2008a: 221). Issues have been raised about the extent to which the process is based on principles of voluntariness and consent, (Lynch, 2016: 167), lack of consistent practices in providing young people information about their rights prior to FGCs (Lynch, 2007-2008), and lack of 
sufficient involvement of young people in the FGC process (Morris, 2004: 273). The heavy caseloads of youth justice co-ordinators, who have responsibility for facilitating FGCs, have been pointed to as a potential reason for under-preparation of young people and their families (Lynch, 2008a: 221). Such concerns have the potential to negatively impact on the realisation of the right to participation. Difficulties such as these highlight the need for active and positive steps to be taken to ensure that alternative decision-making forums, such as the FGC, also respect and support the child's right to participate fully. Despite this, the FGC's potential has also been highlighted. In particular, it has been commented that this type of forum helps to give participants a real voice, and ultimately to make "the justice process more accessible, open and inclusive than the mainstream court process" (Cleland \& Quince, 2014: 139). It is important that Youth Advocates, lawyers for young people, are entitled to attend court-ordered FGCs, and this provides an important support for young people to ensure that they can participate to the fullest extent possible within this process.

In relation to procedures in the Youth Court itself, evaluations have highlighted both positive and negative aspects impacting on the young person's right to participate. Deficiencies in the procedure which impact on the participation of the young person in the process include a lack of information provided both to young people and their families, which led to inaccurate expectations about the Youth Court process, and a reduced ability on the part of the families to properly support the young person. Young people also identified issues in relation to the use of legal jargon that resulted in lack of understanding and disengagement (Ministry of Justice, 2011). However, favourable comments were also made about court procedures that facilitated participation. The role of the Youth Court judge was identified as central to the young person's experience, both as a figure of authority, and as being vitally important in engaging the young person (Ministry of Justice, 2011: 13). The role of the Youth Advocate was also highlighted as being a particularly important source of information and explanations for the young person (Ministry of Justice, 2011).

The issue of the training of legal professionals in New Zealand is significant. The Oranga Tamariki Act requires youth justice professionals to have a high degree of specialisation. The procedure for the designation of Youth Court judges is set out under s.435 of the Act. Section 435(3) states that: "A person shall not be designated a Youth Court Judge unless that person is a suitable person to deal with matters within the jurisdiction of a Youth Court by virtue of that person's training, experience, and personality and understanding of the significance and importance of different cultural perspectives and values." The requirements for suitable training, experience, personality and understanding of cultural issues are important in ensuring suitability for these important role. It has been noted that evaluations of the Youth Courts have considered the Youth Court judges to be one of the strengths of the system, and it has been commented that they have "in a very real sense, acted as guardians of the system and have helped to ensure that access to youth justice is guaranteed for all those participating in the system" (Becroft, 2013: 27).

Similar requirements apply to Youth Advocates, the lawyers who represent children. Section 323(2) requires that Youth Advocates appointed by the Court should be "by reason of personality, cultural background, training, and experience, suitably qualified". The Oranga Tamariki Act also provides for the possibility of providing a further layer of support and advocacy, through the appointment of a lay advocate, in addition to legal representation. The function of the lay advocate, according to s.327, is to ensure that the court is made aware of all relevant cultural matters, and to represent the interests of the child's family/whānau. This type of 
representation has the potential to play a very important role in supporting culturallyappropriate participation of children consistent with the traditional role and place of the child in Māori and Pasifika culture (Cleland \& Quince, 2014:120-122; Kaipuke, 2012: 72). In this way, such support measures may provide an important bridge in order to ensure that participation can occur with awareness of such cultural issues.

The New Zealand experience draws particularly strong attention to the importance of the role of professionals in supporting young people to participate meaningfully in court processes. The level and degree of specialisation required appear to be important factors in facilitating the participation of young people appearing before the Youth Court. It is important to note, however, that systemic issues also have an impact on the realisation of this right. The relatively small number of young people appearing before the Youth Court may contribute to the positive aspects of the process. In particular, where sufficient time is allowed to Youth Court judges to deal with the case in a more in-depth manner, the possibility for direct engagement with the young person is increased. Nonetheless, issues around legal jargon and provision of adequate information can continue to hamper effective participation in New Zealand.

Equally, the FGC as the primary decision-making function has the potential to provide a less formal, more participatory space for young people in conflict with the law. Criticisms of the FGC process, however, highlight that young people's ability to participate and the quality of this participation is impacted by the level of information, preparation and support they receive. It is clear that strong positive efforts should equally be made in alternative forums to support young people's participation.

\section{Conclusion}

The challenge of ensuring that child defendants can participate effectively in criminal proceedings is a very real one. Aside from the fact that States have an obligation under the international standards to ensure that this right is vindicated, there are significant practical implications for young people. Ensuring that children have the ability to participate effectively can help to facilitate better outcomes, through ensuring that young people understand what is required of them, and through fostering greater engagement (Rap, S., 2016: 101). Particular challenges also arise in securing the meaningful participation of children presenting with learning, behavioural, or intellectual difficulties.

An examination of the legal framework and the implementation of the legal provisions in practice in the Republic of Ireland and New Zealand highlight common issues that hamper the participation of the child, and measures which can be taken in order to support more meaningful participation. It is clear that strong, positive steps need to be taken by State authorities in order to ensure that children's rights are effective. A number of important points emerge from this examination.

First, it is important that strong legislative statements and practice directions exist which fully reflect the international standards. While several important provisions in Part VI of the Children Act 2001 ensure that young people being questioned by Gardaí have the right to the presence of a support person, the appropriateness and role of this person is not made clear in the legislation. This has a knock-on impact on the interpretation of the protections by the courts. In New Zealand, where much stronger legislative protections for children's rights are provided in the investigation stage, courts been staunch in upholding the importance of these provisions in a robust and child-centred way.

Second, the implementation of these principles must be paid careful attention to. While provision for FGCs within the Irish context exist, they are rarely used, whereas 
they form an integral part of the New Zealand system. Kilkelly has highlighted that non-implementation of statutory provisions has the potential to directly affect young people's experiences of the criminal justice system, and their outcomes (Kilkelly, $2014 ; 222)$. The international standards require that measures must not be mere token gestures (Committee on the Rights of the Child, General Comment No. 12: para 132). It is not enough for the legislation to provide for these processes if, because of resources or lack of confidence in the measures, they are not implemented. In the process, children in conflict with the law lose out on the potential beneficial impact of these processes on their ability to participate.

Third, there is a need for the judiciary to be willing to interpret statutory and Constitutional guarantees in a manner consistent with the requirements of the international standards. This also requires judges to take into account the differences in capacity, understanding and maturity between young defendants and adult defendants, and to recognise that these real differences need to be reflected in the interpretation of legal guarantees. Sandberg has drawn attention to the important role of the courts in domesticating international children's rights standards, and highlighted the significant impact of the decisions of national courts in incorporating children's rights into domestic law (Sandberg, 2014). It is evident that the guiding principles contained in s.208 of the Oranga Tamariki Act in New Zealand, which emphasise the vulnerability of the child and the need for child-centred procedures, has acted as strong guiding principles for the decisions of the judiciary in interpreting specific provisions. The Irish courts have also shown a willingness to interpret fair trial guarantees under Article 38.1 of the Constitution in a way that was sensitive to the particular circumstances of children. While the Irish courts have not considered the meaning of "effective participation" of children in any detail thus far, if and when such consideration does take place, it is submitted that an interpretation of the law which shows an awareness of the vulnerabilities and particular circumstances of children, and of the requirements of the international standards, will be necessary in order to support to full realisation of the child's right to effective participation. It is only through a child-centred approach to the interpretation of general due process guarantees that they can be made meaningful for children at a practical level.

Fourth, there is a need to examine systemic barriers to the realisation of the child's right to effective participation. The relatively low numbers of young people in conflict with the law appearing before the Youth Court seems to contribute to the fact that more time and resources available are to facilitate more direct engagement with young people. While this type of direct engagement can be a particularly effective way to create a meaningful space for the voice of the child to be heard, pressures from heavy workloads, and a scarcity of time and resources can negatively impact on the ability to create this space.

Fifth, there is a clear and strong need for adequate training of professionals. One of the strongest lessons to emerge from the comparative study of the Republic of Ireland and New Zealand relates to the importance the role of legal professionals in supporting children to participate effectively. This requires specialised training for the professionals involved, particularly judges and lawyers. The New Zealand Oranga Tamariki Act contains detailed requirements relating to the qualifications and training for legal professionals. This appears to have a direct impact on the quality of young people's understanding and participation, as evidenced by evaluations of Youth Court procedure. On the other hand, the ad hoc nature of training of legal professionals in youth justice issues in Ireland presents a real barrier for supporting the effective participation of children. The need for "uniform levels of training" in communicating 
with children for all legal professionals has been noted in the context of child care proceedings in Ireland (Parkes et. al., 2015: 444), and this need is equally urgent in the context of criminal proceedings.

Finally, the inclusion of non-legal professionals, such as lay advocates in New Zealand, and intermediaries in Ireland, in criminal processes provide an important additional layer of support for young people. This is particularly important where the child has particular issues or vulnerabilities that may negatively impact on his or her ability to participate.

It is notable that the youth justice systems of both Ireland and New Zealand are in a period of transition. While significant changes to the legislative framework have already been introduced in New Zealand, and are in the process of being rolled out, Ireland is entering into a stage of reconsideration of the Children Act 2001. In both jurisdictions, this provides an opportunity to review the ways in which children in conflict with the law are supported, encouraged and assisted to participate meaningfully in criminal processes. Important lessons can be learned through the efforts made to support children's participation in both jurisdictions, and it will be important to take these lessons into consideration in future developments in this area.

\section{Bibliography}

An Garda Síochána, Code of Practice on Access to a Solicitor by Persons in Garda Custody (Dublin: An Garda Síochána, April 2015)

Arthur, R., "Giving effect to young people's right to participate effectively in criminal proceedings" (2016) 28(3) Child and Family Law Quarterly 223

Becroft, A., "Children and Young People in Conflict with the Law: Asking the Hard Questions" (2006) 57(4) Juvenile and Family Court Journal 1

Becroft, A., "Access to Youth Justice in New Zealand: 'The Very Good, the Good, the Bad and the Ugly"' (2013) 18 Auckland University Law Review 23

Carroll, J., Meehan, E. \& McPhillips, S., The Children Court: A National Study

(Dublin: Association for Criminal Justice Research and Development, March 2007)

Cleland, A. \& Quince, K., Youth Justice in Aotearoa New Zealand: Law, Policy and Critique (Wellington: LexisNexis, 2014)

Committee on the Rights of the Child, General Comment No. 10: Children's rights in juvenile justice (CRC/C/GC/10, 25 ${ }^{\text {th }}$ April 2007)

Committee on the Rights of the Child, General Comment No. 12: The right of the child to be heard (CRC/C/GC/12, $1^{\text {st }}$ July 2009)

Council of Europe, Guidelines of the Committee of Ministers of the Council of Europe on child-friendly justice (adopted by the Committee of Ministers of the Council of Europe on $17^{\text {th }}$ November 2010)

Dail Eireann Debates, Vol. 518, No. 1, Wednesday $12^{\text {th }}$ April 2000

Deuchar, R. \& Sapouna, M., “'It's harder to go to court yourself because you don't really know what to expect': Reducing the negative effects of court exposure on young people - Findings from an Evaluation in Scotland" (2016) 16(2) Youth Justice 130

District Court, Children Court Bench Book (May 2015)

Forde, L., “'Welfare' and 'Justice' in Irish Youth Justice: A Children's Rights Analysis of Diverse Approaches to Youth Justice" (Unpublished PhD Thesis, University College Cork, 2018) 
Grisso, T., Steinberg, L., Woolard, J., Cauffman, E., Scott, E., Graham, S., Lexcen, F., Dickon Reppucci, N. \& Schwartz, R., "Juveniles' Competence to Stand Trial: A Comparison of Adolescents' and Adults' Capacities as Trial Defendants" (2003) 27(4) Law and Human Behaviour 333

Hall, M., "Children giving evidence through special measures in the criminal courts: progress and problems" (2009) 21(1) Child and Family Law Quarterly 65

Henwood, C. \& Stratford, S., New Zealand's Gift to the World: The Youth Justice Family Group Conference (Wellington: The Henwood Trust, 2014)

Hollingsworth, "Judicial approaches to children's rights in youth crime" (2007) 19(1)

Child and Family Law Quarterly 42

Kaipuke Consultants Ltd., Evaluation of the Early Outcomes of Ngā Kooti Rangatahi: Final Report (17 December 2012) available at www.justice.govt.nz

Kemp, V., Pleasence, P. \& Balmer, N.J., "Children, Young People and Requests for Police Station Legal Advice: 25 years on from PACE" (2011) 11(1) Youth Justice 28 Kilkelly, U. "Youth Courts: The Irish Experience" (2008) 8 Youth Justice 39

Kilkelly, U. \& Forde, L., "Human Rights Law and Juvenile Justice: Emerging Law and Practice", Weber, L., Fishwick, E. \& Marmo, M. (eds.) The Routledge International Handbook of Criminology and Human Rights (London and Newton: Routledge, 2016), p.460

Kilkelly, U., "Diverging or Emerging from Law? The Practice of Youth Justice in Ireland" (2014) 14(3) Youth Justice 212

Kilkelly, U., Youth Justice in Ireland: Tough Lives, Rough Justice (Dublin: Irish Academic Press, 2006)

Lynch, N., "Respecting Legal Rights in the New Zealand Youth Justice Family Group Conference" (2007-2008) 19(1) Current Issues in Criminal Justice 75

Lynch, N., "Young Suspects" (2008b) New Zealand Law Journal 257

Lynch, N., "Youth Justice in New Zealand: A Children's Rights Perspective" (2008a)

8(3) Youth Justice 215

Lynch, N., Youth Justice in New Zealand ( $2^{\text {nd }}$ ed) (Wellington: Thomson Reuters, 2016)

Ministry of Justice, Youth Court Research: Experiences and views of young people, their families and professionals (September 2011)

Morris, A., "Youth Justice in New Zealand" (2004) 31 Crime and Justice 243

O’Malley, T., The Criminal Process (Dublin: Roundhall Thompson Reuters, 2009)

Parkes, A., Children and International Human Rights Law: The Right of the Child to be Heard (London and New York: Routledge, 2013)

Parkes, A., Shore, C., O’Mahony, C. \& Burns, K., "The right of the child to be heard? Professional experiences of child care proceedings in the Irish district court" (2015)

27(4) Child and Family Law Quarterly 423

Parry, R.G., "Protecting the juvenile suspect: what exactly is the appropriate adult supposed to do?" (2006) 18(3) Child and Family Law Quarterly 373

Probation Service, Annual Report 2015 (Dublin: Probation Service, 2015)

Rap, S., "A Children's Rights Perspective on the Participation of Juvenile Defendants in the Youth Court" (2016) 24(1) International Journal of Children's Rights 93

Sandberg, K., "The Role of National Courts in Promoting Children's Rights" (2014) 22(1) International Journal of Children's Rights 1

Seymour, M. \& Butler, M., Young People on Remand (Dublin: Office of the Minister for Children and Youth Affairs, 2008)

Stone, N., "Special Measures for Child Defendants: A Decade of Developments" (2010) 10(2) Youth Justice 174 
Walsh, D., "Balancing due process values with welfare objectives in juvenile justice procedure: Some strengths and weaknesses in the Irish approach" (2008) 3(2) Youth Studies Ireland 3

Weijers, I., "Requirements for Communication in the Courtroom: A Comparative Perspective on the Youth Court in England/Wales and the Netherlands" (2004) 4(1) Youth Justice 22 